\title{
PENGARUH EXPERIENTIAL MARKETING TERHADAP KEPUASAN KONSUMEN DAN MINAT BELI ULANG DI WARUNG KOPI KLOTOK, KALIURANG, YOGYAKARTA
}

\author{
Irma Yanti Febrini' ${ }^{1}$, Retno Widowati PA ${ }^{2}$, Misbahul Anwar ${ }^{3}$ \\ Manajemen, Universitas Muhammadiyah Yogyakarta \\ Yogyakarta, Indonesia \\ irma.yanti.2014@pasca.umy.ac.id, ifebrinimail@gmail.com, retno.widowati@umy.ac.id, \\ misbahulanwar@umy.ac.id
}

\begin{abstract}
This research is about analyzing the influence of Experiential Marketing on consumer satisfaction and repurchase intention at Warung Kopi Klotok, Kaliurang, Yogyakarta. It is a marketing element for the repurchase intention who obtain customer satisfaction through elements of experiential marketing, namely sense, feel, think, act, and relate. Obtaining data directly through a distribution questionnaire, with the number of samples meeting the requirements of a purposive sample of 247 respondents. The data analysis technique used in this study is Structural Equation Modelling (SEM) with the Moment Structure Analysis (AMOS) program version 22. The results of the study show four conclusions namely experiential marketing has a positive and significant effect on customer satisfaction, experiential marketing has a positive and significant effect on repurchase intention, customer satisfaction has a positive and significant effect on repurchase intention, and customer satisfaction is able to mediate marketing experience to repurchase intention.
\end{abstract}

Keywords: Experiential Marketing, customer satisfaction, repurchase intention

\begin{abstract}
Abstrak
Penelitian ini bertujuan untuk menganalisa pengaruh dari experiential Marketing dalam hal kepuasan konsumen dan niat pembelian kembali di warung kopi klotok, Kaliurang, Yogyakarta. Ini adalah elemen pemasaran untuk pembelian kembali niat yang mendapatkan kepuasan pelanggan melalui elemen dari pemasaran experiential, yaitu merasakan, merasa, berpikir, bertindak, dan berhubungan. Memperoleh data secara langsung melalui kuesioner distribusi, dengan jumlah sampel memenuhi persyaratan sampel purposive dari 247 responden. Teknik analisis data yang digunakan dalam penelitian ini adalah struktural persamaan pemodelan (SEM) dengan saat program analisis struktur (AMOS) versi 22. Hasil studi menunjukkan empat kesimpulan yaitu experiential Marketing memiliki efek positif dan signifikan pada kepuasan pelanggan, experiential Marketing memiliki efek positif dan signifikan atas niat membeli kembali, kepuasan pelanggan memiliki efek positif dan signifikan pada niat pembelian kembali, dan kepuasan pelanggan mampu menengahkan pengalaman pemasaran untuk membeli kembali niat.
\end{abstract}

Kata kunci: experiential Marketing, kepuasan pelanggan, niat membeli kembali 
Jurnal Manajemen Bisnis, Vol 10. No.1, Maret 2019, E-ISSN:2622-6308 P-ISSN:2086-8200

Website: http://journal.umy.ac.id/index.php/mb

DOI:10.18196/mb.10167

\section{PENDAHULUAN}

\section{Latar Belakang Masalah}

Konsep experiential marketing oleh Bernd Schmitt (1999) merupakan cara kreatif untuk menyampaikan pesan produk dan jasa dengan melibatkan konsumen secara fisik dan emosi (psikologi dan respon emosional) mereka agar terdorong untuk berpikir, bertindak, menjalin relasi, sehingga menimbulkan kepuasan sebagai konsumen lalu tergerak untuk melakukan pembelian ulang. Poin utamanya adalah melakukan pendekatan unik, positif, dengan interaksi yang berkesan bagi konsumen. Experiential marketing bukan konsep baru tetapi masih relevan untuk dikaji ulang saat ini, dan sektor kuliner dipilih menjadi bahasan, karena sangat potensial untuk dikembangkan, mengingat makanan dan minuman merupakan kebutuhan yang utama bagi manusia, yang akan selalu mendapat ruang untuk terus bertumbuh dan berkembang.

Perkembangan e-commerce yang ada saat ini, memberikan kemudahan termasuk melakukan order kuliner secara online dan menunggu kurir datang mengantarkan orderan ke alamat, namun ditengah kemudahan itu ada nilai-nilai yang tetap saja dibutuhkan konsumen yaitu nilai pengalaman fisik yang tidak akan diperoleh ketika berbelanja secara online. Bermacam alasan yang membuat pelanggan tertarik untuk berbelanja dan menikmati kuliner di luar rumah mereka, diantaranya karena adanya mobilitas yang tinggi ataupun sekedar singgah untuk bertemu kolega, untuk rekreasi dengan keluarga maupun kelompok bermain (peer group) untuk mengisi waktu luang menikmati sajian makan dan minum bersama, ada yang mencari tempat bersantai dengan suasana yang modern, tempat yang unik, tempat yang dilengkapi dengan sarana yang edukatif, dan tempat bersantai dengan nuansa alami yang bisa menjadi sarana penghilang stress dan keletihan dari rutinitas seharihari, dan tujuan utama dalam rekreasi kuliner adalah orang-orang datang ke objek wisata kuliner tidak hanya untuk makan, tetapi juga untuk menghabiskan waktu mereka dan memperoleh kegembiraan. Sesungguhnya pelanggan tidak membeli barang atau jasa, tetapi membeli manfaat dan nilai dari sesuatu yang ditawarkan. (Adam 2015).

Warung Kopi Klotok Kaliurang hadir menampilkan diri (branding) dengan konsep orisinalitas kesederhanaan pemandangan asri suasana pesawahan dan gunung Merapi di pedesaan dengan hawa yang sejuk dan lingkungan yang segar khas lingkungan alami yang memiliki pesona tersendiri, lokasi yang agak jauh dari pusat kota namun tetap bisa diakses dengan kendaraan pribadi, serta menawarkan konsep pengalaman makan di dalam rumah 
Jurnal Manajemen Bisnis, Vol 10. No.1, Maret 2019, E-ISSN:2622-6308 P-ISSN:2086-8200

Website: http://journal.umy.ac.id/index.php/mb

DOI:10.18196/mb.10167

gaya pedesaan dengan kesederhanaan sajian masakan rumahan dari racikan bumbu alami khas Jawa yang dimasak dengan tungku kayu bakar tradisional di sebuah rumah makan berbentuk bangunan kuno tanpa plafon, pengunjung mengantri makanan sekaligus bisa menikmati makanan di ruang makan, di halaman depan warung maupun di halaman rumah pemilik yang berhadapan langsung dengan sawah sambil menggelar tikar, di dapur tradisional sambil memandang warna asap menghitam yang menempel di area sekitar tungku menambah kesan hangat khas dapur pedesaan, inilah yang menjadi menjadi diferensiasi Warung Kopi Klotok dalam menyerap pangsa pasarnya sendiri dengan berani menampilkan orisinalitas dan otentik suasana desa untuk menarik minat konsumen. Konsumen yang datang sangat beragam mulai dari warga sekitar, mahasiswa, wisatawan lokal, hingga artis, tokoh publik dan pejabat juga mengunjungi Warung Kopi Klotok ini.

\section{Tujuan Penelitian}

Untuk meneliti lebih jauh tentang konsep experiential marketing elemen (sense, feel, think, act, dan relate) yang diimplementasikan di Warung Kopi Klotok.

\section{KAJIAN TEORI}

\section{Experiential Marketing}

Experiential Marketing merupakan suatu proses penawaran produk dan jasa oleh pemasar kepada konsumen dengan perangsangan emosi konsumen yang menghasilkan berbagai pengalaman bagi konsumen (Schmitt 1999), melalui panca indera (sense), afektif/perasaan (feel), kognitif/ berpikir kreatif (think), fisik, perilaku dan gaya hidup (act), dan identitas sosial yang dihasilkan dari hubungan dengan kelompok referensi atau budaya (relate) yang dikenal sebagai modul pengalaman strategis atau Strategic Experiential Modules (SEMs).

Pelanggan dapat membedakan satu produk atau layanan dari yang lain karena mereka mengalami sendiri secara langsung dalam proses memilih dan mengkonsumsi produk atau layanan menggunakan lima pendekatan yaitu akal, merasa, berpikir, bertindak, dan berhubungan (Andreani 2007). Schmitt (1999) mendefinisikan kata "pengalaman" adalah sebagai suatu pengalaman peristiwa pribadi yang terjadi karena rangsangan tertentu yang disediakan oleh pemasar sebelum dan sesudah pembelian barang dan jasa. Sementara Pine II \& Gilmore (1999) dalam Lokito dan Dharmayanti (2013), mengatakan bahwa 
Jurnal Manajemen Bisnis, Vol 10. No.1, Maret 2019, E-ISSN:2622-6308 P-ISSN:2086-8200

Website: http://journal.umy.ac.id/index.php/mb

DOI:10.18196/mb.10167

pengalaman adalah peristiwa yang terjadi dan mengikat setiap individu secara pribadi. Menurut Chandra (2008), experiential marketing adalah strategi pemasaran yang dibungkus dalam bentuk kegiatan sehingga memberi pengalaman yang dapat membekas dihati konsumen. Menurut Smilansky (2009) experiential marketing adalah proses mengidentifikasi dan memuaskan kebutuhan konsumen dan aspirasi yang menguntungkan, melibatkan konsumen melalui komunikasi dua arah yang membawa kepribadian merek untuk hidup dan menambah nilai target audiens. Menurut Kartajaya (2004), experiential marketing adalah suatu konsep pemasaran yang bertujuan untuk membentuk konsumen-konsumen yang loyal dengan menyentuh emosi mereka dan memberikan suatu feeling yang positif terhadap produk dan jasa.

\section{Kepuasan Pelanggan}

Menurut Kotler and Keller (2012), kepuasan pelanggan terjadi ketika harapan pelanggan sesuai atau dapat dipenuhi oleh kinerja atau mendekati terpenuhi bahkan dapat melebihi harapan pelanggan. Pelanggan adalah seseorang yang secara kontinu dan berulang kali datang ke suatu tempat yang sama untuk memuaskan keinginannya dengan memiliki suatu produk atau mendapatkan suatu jasa dan membayar produk atau jasa tersebut. Kepuasan terjadi sebagai akibat dari respons psikologis yang terjadi oleh konsumen yang membandingkan kesenjangan antara apa yang diharapkan sebelumnya dan apa yang dialami pasca konsumsi (Lee, Hsiao\&Yang, 2010). Menurut Tjiptono (2014) kepuasan pelanggan merupakan penilaian evaluasi (evaluative) purnabeli, yang dihasilkan dari seleksi pembelian spesifik. Menurut Mowen (1995) dalam Tjiptono (2014) kepuasan konsumen merupakan sikap secara keseluruhan terhadap suatu produk atau jasa setelah perolehan (acquisition) dan pemakaiannya. Menurut Oliver (1997) dalam Tjiptono (2014) kepuasan pelanggan adalah evaluasi purnabeli antara persepsi terhadap kinerja alternatif produk atau jasa yang dipilih memenuhi atau melebihi harapan. Menurut Solomon (2004) kepuasan konsumen ditentukan oleh perasaan keseluruhan, atau sikap, seseorang tentang suatu produk setelah dibeli, konsumen terlibat dalam proses evaluasi yang konstan terhadap halhal yang mereka beli ketika mereka mengintegrasikan produk-produk ini ke dalam aktivitas konsumsi harian mereka. Dalam Suryadana \& Octavia, (2015) terdapat tiga metode yang bisa dipakai untuk mengukur tinggi tidaknya kepuasan pelanggan: melakukan survei berkala (periodic survey), mengukur tingkat kehilangan pelanggan (customer loss rate) dengan 
Jurnal Manajemen Bisnis, Vol 10. No.1, Maret 2019, E-ISSN:2622-6308 P-ISSN:2086-8200

Website: http://journal.umy.ac.id/index.php/mb

DOI:10.18196/mb.10167

mengamati secara langsung konsumen yang menjadi pelanggan tetap, menyimpan informasi dari pelanggan. Menurut Kotler (2012) dalam Suryadana \& Octavia (2015) berikut ciri-ciri konsumen yang merasa puas: loyal terhadap produk, adanya komunikasi dari mulut ke mulut yang bersifat positif (word of mouth communication), perusahaan yang telah memberikan kepuasan akan menjadi pertimbangan utama ketika ingin membeli merek lain.

\section{Minat Beli Ulang}

Menurut Kotler Keller (2007), terdapat beberapa faktor utama yang mempengaruhi minat pelanggan untuk melakukan pembelian ulang (repurchase intention) yaitu faktor psikologis, faktor pribadi dan faktor sosial. Jadi dapat disimpulkan bahwa minat beli ulang (repurchase intention) adalah keputusan pelanggan untuk melakukan pembelian ulang di masa mendatang, disebabkan oleh adanya kepuasan dan kepercayaan, dimana keputusan pembelian ulang oleh pelanggan ini bisa mendatangkan keuntungan (benefit) bagi perusahaan. Dalam Kusumawati (2011) menerangkan bahwa Repurchase Intention dipengaruhi oleh kepuasan dan ketidakpuasan. Intention adalah suatu kecendrungan untuk melakukan suatu tindakan terhadap objek (Assael, 1998). Pelanggan yang merasa puas akan mengulangi lagi pembeliannya untuk yang kedua kali, ketiga kali, dan seterusnya. Mereka tidak akan lagi mempertimbangkan untuk hal-hal sebagaimana yang dilakukan pada saat melakukan pembelian untuk yang pertama kali. Repurchase Intention ini merupakan indikasi dari loyalitas pelanggan, disamping indikator lainnya seperti adanya rekomendasi positif terhadap perusahaan yang dilakukan oleh satu konsumen dan disampaikan kepada konsumen lainnya. Menurut Hellier, et al. 2003 dalam Tanzil dkk (2015), minat beli ulang adalah tentang membeli kembali sebuah layanan dari perusahaan yang sama, dan cenderung dilakukan secara berkala sebagai nilai individu dengan mempertimbangkan situasi sekarang dan mempertimbangkan keadaan yang memungkinkan. Menurut Nigam, (2012) dalam Sebopa (2016), experiential marketing dapat menjadi pemberi pengaruh utama untuk niat pembelian kembali karena memungkinkan pelanggan untuk terikat dengan produk atau layanan yang kemudian dapat mengarah ke loyalitas pelanggan. Menurut Hellier, et al., (2003) dalam Lunette \& Andreani (2017), minat beli ulang adalah sebagai nilai individu tentang membeli kembali sebuah layanan yang dari perusahaan yang sama, serta cenderung dilakukan secara berkala dengan mempertimbangkan situasi sekarang dan keadaan yang memungkinkan. Menurut Yi \& La, (2004), dalam Unjaya \& Santoso (2015), 
Jurnal Manajemen Bisnis, Vol 10. No.1, Maret 2019, E-ISSN:2622-6308 P-ISSN:2086-8200

Website: http://journal.umy.ac.id/index.php/mb

DOI:10.18196/mb.10167

minat beli ulang adalah salah satu bentuk loyalitas dalam bentuk perilaku yang menunjukkan adanya ketertarikan pelanggan tetap untuk melakukan pembelian kembali produk atau jasa dimasa depan dengan penyedia yang sama.

\section{HIPOTESIS}

Experiential marketing merupakan strategi yang digunakan pemasar untuk membentuk pengalaman yang mengesankan (memorable experience) bagi konsumen, dengan mengusahakan supaya pelanggan merasa feel good dan membuat emosi pelanggan sesuai dengan keinginan pemasar. Pemasaran berdasarkan pengalaman dapat menciptakan preferensi konsumen yang membedakan suatu produk atau jasa yang lainnya. Kepuasan pelanggan dapat digunakan oleh pemasar untuk menciptakan yang lebih penting yaitu mempertahankan pelanggan lama, karena biaya yang diperlukan untuk mendapat konsumen baru jauh lebih besar. Ketika konsumen merasa puas mereka cenderung bersikap loyal, dimana mereka akan melakukan beli ulang dari produsen yang sama (repurchase intention).

\section{Pengaruh Experiential Marketing terhadap kepuasan konsumen}

Mengacu pada penelitian Kanoipate (2015) bahwa experiential marketing memiliki dampak terbesar pada kepuasan pelanggan. Penelitian Hyunjin (2003) bahwa experiential marketing telah memiliki pengaruh signifikan terhadap kepuasan pelanggan dan dan loyalitas pelanggan. Penelitian Ozturk (2015) bahwa experiential marketing memiliki pengaruh signifikan pada kepuasan pelanggan. Penelitian Tetanoe \& Dharmayanti (2014) experiential marketing yang berpengaruh terhadap kepuasan pelanggan semakin puas dengan pengalaman dan perasaannya dengan kontribusi terkuat adalah dimensi feel. Penelitian Yang (2009) bahwa sense adalah faktor yang menunjukkan hubungan yang signifikan pada kepuasan konsumen dan niat beli kembali. Penelitian Razanah, Kumadji \& Kusumawati (2013) bahwa terdapat pengaruh yang positif dan signifikan antara experiential marketing terhadap kepuasan konsumen. Penelitian Lee et.al (2010) bahwa experiential marketing memiliki efek positif yang signifikan terhadap kepuasan pelanggan. Dan penelitian lainnya Ming (2010), Tanzil dkk (2017), Oeyono \& Dharmayanti (2013), Tetanoe \& Dharmayanti (2014), Christian \& Dharmayanti (2013), Zena \& Hadisumarto (2012), juga menunjukkan bahwa experiential marketing berpengaruh positif signifikan terhadap 
Jurnal Manajemen Bisnis, Vol 10. No.1, Maret 2019, E-ISSN:2622-6308 P-ISSN:2086-8200

Website: http://journal.umy.ac.id/index.php/mb

DOI:10.18196/mb.10167

kepuasan konsumen. Berdasarkan pemikiran tersebut dapat dirumuskan Hipotesis 1: Experiential Marketing berpengaruh positif signifikan terhadap kepuasan konsumen.

\section{Pengaruh Experiential Marketing berpengaruh terhadap minat beli ulang}

Mengacu pada penelitian Tanzil, dkk (2017) diketahui bahwa variabel act yang paling dominan dalam mempengaruhi repurchase intention yang dapat dilihat dari nilai mean tertinggi responden sehingga mampu untuk menimbulkan minat beli ulang. Penelitian Tetanoe \& Dharmayanti (2014) menunjukkan bahwa Experiential Marketing memiliki pengaruh secara langsung terhadap pembelian ulang. Penelitian lainnya oleh Setyono dkk (2017) menunjukkan bahwa elemen think, act, dan relate (paling dominan) berpengaruh positif dan signifikan terhadap minat beli ulang, sedangkan elemen sense dan feel berpengaruh positif namun tidak signifikan terhadap minat beli ulang. Penelitian Lunette \& Andreani (2017) bahwa experiential marketing terutama elemen feel berpengaruh terhadap minat pembelian ulang. Berdasarkan pemikiran tersebut dapat dirumuskan Hipotesis 2: Experiential Marketing berpengaruh positif signifikan terhadap minat beli ulang.

\section{Pengaruh Kepuasan konsumen berpengaruh terhadap minat beli ulang}

Mengacu pada penelitian Sebopa (2016) ditemukan ada hubungan positif signifikan antara kepuasan pelanggan dan niat beli kembali, semakin puas pelanggan, semakin besar kemungkinan mereka memiliki niat untuk membeli kembali merek yang sama. Penelitian Hyunjin (2013) menunjukkan bahwa kepuasan pelanggan penting untuk niat kembali dan ditandai dengan semakin tinggi frekuensi kunjungan. Penelitian Tetanoe \& Dharmayanti (2014) menunjukkan bahwa dengan adanya peningkatan pada kepuasan konsumen akan memberikan pembelian ulang. Berdasarkan pemikiran tersebut dapat dirumuskan Hipotesis 3: Kepuasan konsumen berpengaruh terhadap minat beli ulang.

\section{Pengaruh Kepuasan konsumen sebagai Variabel Intervening mampu memediasi variabel experiential marketing terhadap minat beli ulang.}

Penelitian Christian \& Dharmayanti (2013) menyimpulkan bahwa kepuasan konsumen dapat menjadi mediator antar kelima dimensi dari experiential marketing terhadap loyalitas pelanggan. Berdasarkan pemikiran tersebut dapat dirumuskan Hipotesis 4: 
Jurnal Manajemen Bisnis, Vol 10. No.1, Maret 2019, E-ISSN:2622-6308 P-ISSN:2086-8200

Website: http://journal.umy.ac.id/index.php/mb

DOI:10.18196/mb.10167

Kepuasan konsumen sebagai Variabel Intervening mampu memediasi variabel experiential marketing terhadap minat beli ulang.

\section{MODEL PENELITIAN}

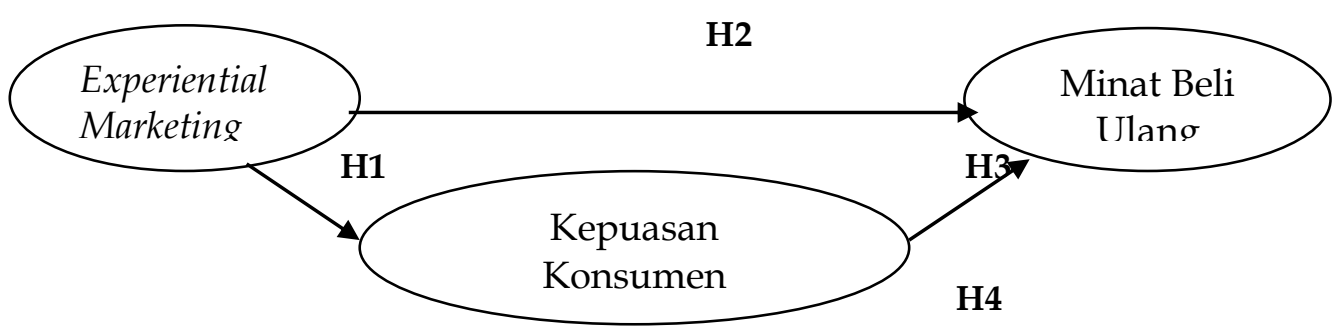

Gambar 1

Model penelitian, sumber: penelitian terdahulu Ozturk (2015)

\section{METODE PENELITIAN}

\section{Objek dan Subjek Penelitian}

Objek penelitian ini adalah Warung Kopi Klotok, Kaliurang, Yogyakarta, dengan subjek penelitian adalah para pengunjungnya dengan rentang usia minimal 17 tahun ke atas.

\section{Definisi Operasional Penelitian}

Berikut adalah definisi operasional variabel dan indikatornya:

Tabel 1

Definisi Operasional Penelitian

\begin{tabular}{|c|c|c|c|}
\hline No & Variabel & Definisi Operasional & Indikator \\
\hline 1 & $\begin{array}{l}\text { Experiential } \\
\text { Marketing } \\
\text { (Bernd Schmitt, } \\
\text { 1999) }\end{array}$ & $\begin{array}{lr}\text { Merupakan } & \text { suatu } \\
\text { usaha } & \text { yang } \\
\text { digunakan } & \text { oleh } \\
\text { pemasar } & \text { untuk } \\
\text { mengemas } & \text { produk } \\
\text { sehingga } & \text { mampu } \\
\text { menawarkan } & \\
\text { pengalaman emosi } \\
\text { hingga menyentuh } \\
\text { hati dan perasaan } \\
\text { konsumen. }\end{array}$ & $\begin{array}{l}\text { 1. Sense (pengalaman melalui panca } \\
\text { indera penglihatan, pendengaran, } \\
\text { peraba, penciuman, pengecapan rasa) } \\
\text { bertujuan untuk menciptakan } \\
\text { keindahan, estetika, kegembiraan, } \\
\text { kesenangan melalui rangsangan } \\
\text { indera, aroma, perhatian, mudah } \\
\text { digunakan. } \\
\begin{array}{l}\text { 2. Feel (pengalaman melalui } \\
\text { perasaan, emosi, suasana hati seperti } \\
\text { perasaan senang, semangat, rileks, } \\
\text { peduli). }\end{array}\end{array}$ \\
\hline
\end{tabular}


2 Kepuasan

Pelanggan

(Kotler \& Keller,

2012.

Dalam

Tjiptono, 2014)
Merupakan perasaan senang atau kecewa seseorang yang berasal dari perbandingan antara kesan terhadap kinerja hasil suatu produk atau jasa dengan harapan yang dimiliki.

3 Minat Beli Ulang (Yi \& La, 2004 dalam Unjaya \& Santoso, 2015) dan (Yan \& Yu, 2013 dalam Tanzil, $\mathrm{dkk}$, 2017).
Merupakan salah satu bentuk loyalitas secara perilaku atau dalam bentuk perilaku yang menunjukkan ketertarikan pelanggan tetap untuk melakukan transaksi kembali dengan penyedia produk atau jasa di masa depan.

\section{Think (pengalaman dengan mendorong keterlibatan konsumen) seperti berpikir dan keingintahuan, imajinasi.}

4. Act (pengalaman yang berkaitan dengan pola perilaku, pengalaman fisik dan gaya hidup sebagai hasil dari interaksi dengan orang lain).

5. Relate (pengalaman yang menjelaskan suatu hubungan dengan orang lain atau kelompok sosial, pekerjaan, gaya hidup, etnis, hubungan dengan orang lain).

1. Kepuasan pengalaman secara keseluruhan, suasana hati yang baik, kesenangan.

2. Terpenuhinya harapan pelanggan.

3. Perasaan puas pelanggan terhadap kualitas pelayanan yang diberikan.

4. Kesediaan pelanggan untuk merekomendasikan kepada pihak lain. 5. Terkait dengan pilihan yang bagus, produk yang memuaskan, fasilitas fisik yang memuaskan, pelayanan yang memuaskan.

1. Minat untuk membeli produk (willingness to buy).

2. Minat membeli ulang dengan menambah variasi produk (more repurchase).

3. Minat membeli kembali di masa depan (trend to repurchase)

4. Minat membeli ulang produk yang sama/memiliki preferensi utama pada suatu produk (repurchase the same of product).

Sumber: Buku dan Penelitian Terdahulu

\section{Populasi dan Teknik Pengambilan Sampel}

Populasi dan sampel dalam penelitian ini adalah pengunjung Warung Kopi Klotok, Kaliurang, Yogyakarta, Teknik pengambilan sampel adalah Purposive Sampling, merupakan salah satu teknik Non Random Sampling dengan menetapkan ciri khusus yaitu sampel hanya ditujukan kepada pengunjung yang sedang berkunjung ke Warung Kopi Klotok di 
Jurnal Manajemen Bisnis, Vol 10. No.1, Maret 2019, E-ISSN:2622-6308 P-ISSN:2086-8200

Website: http://journal.umy.ac.id/index.php/mb

DOI:10.18196/mb.10167

Kaliurang Yogyakarta lebih dari satu kali. Pengambilan sampel dengan berdasarkan teknik maximum likelihood estimation (MLE) disarankan 100-200 sampel, dengan pedoman sebanyak 5-10 kali. Dari 32 parameter indikator penelitian, dikalikan interval 5-10 variabel manifest setidaknya peneliti menggunakan 160-320 responden, sedangkan teknik estimasi General Least Square (GLS) untuk sampel berjumlah 200-500 sampel (Ghozali, 2011), sampel awal yang peneliti tetapkan adalah sebanyak 290 responden, dan setelah melalui pensortiran maka sampel yang tersedia untuk diteliti sebanyak 247 sampel. Berikut ini adalah tabel tentang detail pendistribusian kuesioner:

Tabel 2

Detail Pendistribusian Kuesioner

\begin{tabular}{ll}
\hline \multicolumn{1}{c}{ Detail Pendistribusian Kuesioner } & \\
\hline Distribusi awal kuesioner & 290 \\
Kuesioner tidak kembali & 4 \\
Kuesioner kembali & 286 \\
Kuesioner tidak memenuhi syarat Purposive Sampling & 24 \\
(untuk kunjungan harus lebih dari satu kali) & \\
Data responden yang memenuhi syarat & 262 \\
Data responden tersisa setelah uji outliers dan akan & 247 \\
dianalisa dengan SEM Amos versi 22 & \\
\hline
\end{tabular}

Sumber: Data diolah (2018)

\section{Variabel Penelitian}

Variabel Eksogen (independen/bebas): experiential marketing yang terdiri dari elemen sense, think, feel, act dan relate. Variabel Intervening: kepuasan konsumen. Variabel Endogen (dependen/terikat): minat beli ulang.

\section{Metode Penelitian}

Penelitian ini adalah model kausalitas (hubungan sebab akibat atau pengaruh) menggunakan metode analisis data Structural Equation Modeling (SEM) dengan program AMOS versi 22 dan SPSS versi 17. 
Jurnal Manajemen Bisnis, Vol 10. No.1, Maret 2019, E-ISSN:2622-6308 P-ISSN:2086-8200

Website: http://journal.umy.ac.id/index.php/mb

DOI:10.18196/mb.10167

\section{HASIL DAN PEMBAHASAN}

\section{Karakteristik Responden}

Berdasarkan hasil analisis deskriptif responden dari 247 responden diketahui bahwa pelanggan Warung Kopi Klotok di dominasi konsumen laki-laki, berusia rentang 21-30 tahun, berpendidikan S1, yang berstatus/pekerjaan sebagai mahasiswa, dengan pendapatan dan pengeluaran berkisar 1-3 juta, yang telah berkunjung lebih dari 3 kali. Sedangkan hasil uji analisis deskripsi variabel experiential marketing dapat dilihat urutan dimensi yang paling tinggi hingga paling rendah dari grafik berikut:

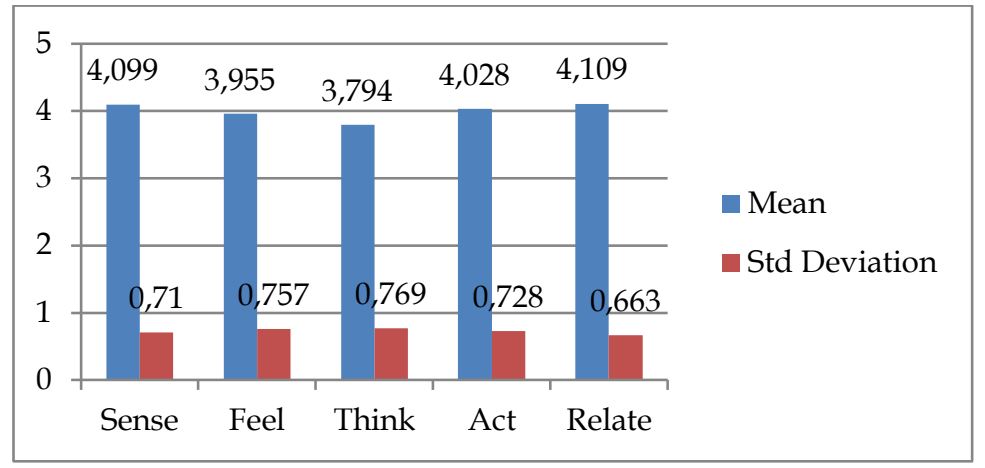

Gambar 2

Grafik Analisis Deskriptif Variabel Experiential Marketing

Dari grafik di atas terlihat dimensi yang tertinggi adalah relate dengan nilai total mean 4.109 pada indikator ingin membagikan pengalaman kuliner kepada teman dan orang lain yang menyukai suasana desa yang alami. Kemudian sense nilai total mean 4.099 pada indikator ketertarikan pengunjung untuk menikmati suhu udara yang sejuk dan segar. Kemudian act dengan nilai total mean 4.028 pada indikator tindakan konsumen karena gaya yang berbeda dan unik dari Warung Kopi Klotok. Kemudian feel dengan nilai mean 3.955 pada indikator merasa nyaman menikmati lingkungan asri pedesaan. Kemudian think dengan nilai mean 3.794 pada indikator tertarik karena adanya keinginan untuk merasakan suasana khas desa. Sedangkan variabel kepuasan konsumen nilai mean tertinggi 4.142 berada pada indikator konsumen merasa puas karena merupakan pilihan yang bagus bagi mereka untuk menikmati kuliner dan pemandangan desa. Variabel minat beli ulang nilai mean tertinggi 3.956 berada pada indikator ingin melakukan beli ulang di waktu mendatang. 
Jurnal Manajemen Bisnis, Vol 10. No.1, Maret 2019, E-ISSN:2622-6308 P-ISSN:2086-8200

Website: http://journal.umy.ac.id/index.php/mb

DOI:10.18196/mb.10167

\section{Hasil Uji Asumsi SEM}

\section{Hasil Uji Outliers}

Berdasarkan hasil uji outliers dapat terdeteksi dengan melihat tabel mahalonobis distance, dalam tabel tersebut data disebut sebagai outliers jika memiliki nilai Mahalanobis dsquared melebihi 43,8202 yaitu nilai Chi-Square pada derajat bebas 19 (karena ada 19 indikator valid yang dianalisis) dan taraf signifikan 0,001. Hasil deteksi outlier menunjukkan bahwa dari 247 data yang dianalisis tidak ada data yang memiliki jarak mahalonobis di atas 43,8202, hal ini menunjukkan bahwa tidak ada outliers dalam data yang dianalisis. Seluruh data dapat dianalisis dengan menggunakan analisis SEM.

\section{Hasil Uji Normalitas}

Berdasarkan hasil uji normalitas menunjukkan bahwa data penelitian telah berdistribusi normal karena nilai kurtosis univariat seluruh indikator telah berada dalam interval $-2,58<\mathrm{z}<2,58$ begitu juga dengan nilai c.r multivariat sebesar -23,141 menunjukkan bahwa cr multivariat tidak berada didalam interval $-2,58<\mathrm{z}<2,58$, hal ini menunjukkan bahwa data yang akan dianalisis tidak beridistribusi normal baik secara univariat maupun multivariat.

\section{Analisa Data dan Uji Hipotesis}

\section{Pengujian Model Struktural}

Uji kelayakan model struktural dengan melihat beberapa kriteria Goodness of fit model seperti nilai Chi Square, probabilitas, df, GFI, AGFI, TLI, CFI RMSEA dan RMR. Berikut ini adalah hasil modifikasi model goodness of fit:

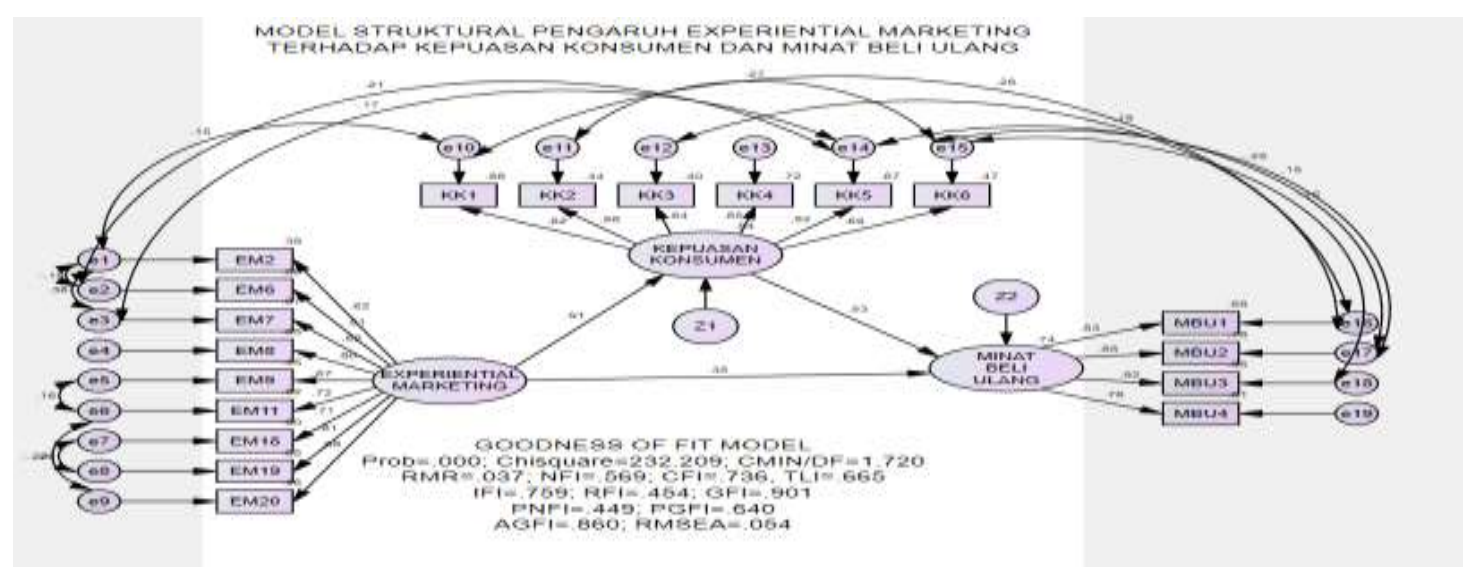

Gambar 3. Model Struktural Goodness of Fit 
Jurnal Manajemen Bisnis, Vol 10. No.1, Maret 2019, E-ISSN:2622-6308 P-ISSN:2086-8200

Website: http://journal.umy.ac.id/index.php/mb

DOI:10.18196/mb.10167

Dalam analisis SEM, model diharuskan memenuhi kriteria goodness of fit model, terutama probabilitas model, karena probabilitas model $>0,05$ menunjukkan bahwa sampel yang digunakan memiliki matriks kovarian sama dengan matriks kovarian populasi, sehingga dapat menunjukkan kondisi populasi sebenarnya, akan tetapi adakalanya model tidak bisa memenuhi kriteria tersebut sehingga model perlu dimodifikasi, modifikasi dilakukan berdasarkan acuan di output AMOS yaitu dengan menghubungkan indikator-indikator yang menurut AMOS saling berkorelasi, setelah dilakukan modifikasi model probabilitas model akan meningkat dan dapat melebihi 0,05 (Ghozali, 2014). Jadi dilakukannya penambahan jalur itu (dimana struktur model SEM nilai error loading factor saling dihubungkan dengan correlation matrix) adalah upaya agar model memenuhi kriteria goodness of fit.

Berdasarkan hasil uji goodness of fit full model diketahui bahwa terdapat 5 indikator dalam kriteria fit, 3 indikator dalam kriteria marginal fit dan 5 indikator dalam kriteria unfit, dapat disimpulkan bahwa secara keseluruhan model penelitian telah memenuhi asumsi goodness of fit, sehingga model penelitian ini layak digunakan untuk uji selanjutnya. Jika terdapat satu atau dua kriteria goodness of fit yang telah terpenuhi, maka dapat dikatakan bahwa model yang dibangun baik dan layak untuk digunakan dalam penelitian selanjutnya (Ghozali, 2014).

Tabel 3

Hasil Pengujian Goodness of Fit Model

\begin{tabular}{llll}
\hline Goodness of fit Index & Cut-Off Value & $\begin{array}{c}\text { Nilai } \\
\text { model }\end{array}$ & Keterangan \\
\hline $\boldsymbol{X}^{2}$ Chi-Square & 178,49 & 232.209 & Unfit \\
$\begin{array}{l}\text { Significant } \\
\text { probability }\end{array}$ & $\geq 0.05$ & 0.000 & Unfit \\
CMIN/DF & $\leq 2.00$ & 1.72 & Fit \\
GFI & $\geq 0.90$ & 0.901 & Fit \\
AGFI & $\geq 0.90$ & 0.860 & Marginal fit \\
CFI & $\geq 0.95$ & 0.736 & Marginal fit \\
TLI & $\geq 0.95$ & 0.665 & Unfit \\
NFI & $\geq 0.90$ & 0.569 & Unfit \\
IFI & $\geq 0.90$ & 0.759 & Marginal fit \\
RMSEA & $\leq 0.08$ & 0.054 & Fit \\
RMR & $\leq 0.05$ & 0.037 & Fit \\
PNFI & $0.600-0.900$ & 0.449 & Unfit \\
PGFI & $0.500-1.000$ & 0.640 & Fit \\
\hline
\end{tabular}

Sumber: Data diolah (2018) 
Jurnal Manajemen Bisnis, Vol 10. No.1, Maret 2019, E-ISSN:2622-6308 P-ISSN:2086-8200

Website: http://journal.umy.ac.id/index.php/mb

DOI:10.18196/mb.10167

\section{Hasil Uji Signifikansi dan Pembahasan}

Uji signifikansi bertujuan untuk menguji ada tidaknya pengaruh signifikan variabel eksogen terhadap variabel endogen. Hipotesis yang dibangun dalam pengujian ini adalah sebagai berikut: Ho: Tidak terdapat pengaruh signifikan variabel eksogen terhadap variabel endogen. Ha: Terdapat pengaruh signifikan variabel eksogen terhadap variabel endogen. Dengan taraf signifikan sebesar 0,05 maka Ho akan ditolak jika nilai signifikan $(\mathrm{P})<0,05$ dan c.r $>1,96$, sedangkan jika nilai signifikan $(\mathrm{P})>0,05$ dan c.r $<1,96$ maka Ho tidak ditolak.

Tabel 4

Hasil Uji Signifikansi

Regression Weights: (Group number 1-Default model)

\begin{tabular}{|c|c|c|c|c|c|c|c|}
\hline & & & Estimate & S.E. & C.R. & $\mathbf{P}$ & Label \\
\hline KK & $<--$ & $\overline{\mathrm{EM}}$ & .903 & .111 & 8.155 & $* * *$ & Par_14 \\
\hline MBU & $<--$ & EM & .372 & .178 & 2.088 & .037 & Par_16 \\
\hline MBU & $<--$ & KK & .580 & .198 & 2.933 & .003 & Par_15 \\
\hline
\end{tabular}

Berdasarkan hasil analisis pada tabel di atas, diperoleh beberapa hasil sebagai berikut:

Nilai p-value pengaruh experiential marketing terhadap kepuasan konsumen adalah

*** dengan CR bertanda positif sebesar 8,155. Oleh karena nilai p-value yang diperoleh < 0,05 dan C.R bertanda positif > 1,96, maka Ho ditolak dan disimpulkan bahwa experiential marketing berpengaruh positif dan signifikan terhadap kepuasan konsumen. Semakin tinggi experiential marketing maka semakin tinggi kepuasan konsumen. Pemasar Warung Kopi Klotok mampu menampilkan indikator-indikator experiential marketing yang baik dan mampu menarik hati serta sesuai dengan apa yang diharapkan konsumen baik dari segi pelayanan, produk kuliner yang cocok di lidah dan fasilitas pendukung yang memadai, ciri khas yang ditawarkan yaitu suasana desa yang asri dan alami di lokasi warung, dan memang dapat langsung diamati dan dirasakan konsumen, maka hal ini telah menimbulkan kepuasan tersendiri bagi konsumen.

Nilai p-value pengaruh experiential marketing terhadap minat beli ulang adalah 0,037 dengan CR bertanda positif sebesar 2,088. Oleh karena nilai p-value yang diperoleh < 0,05 dan C.R bertanda positif > 1,96, maka Ho ditolak dan disimpulkan bahwa experiential marketing berpengaruh positif dan signifikan terhadap minat beli ulang. Semakin tinggi experiential marketing konsumen maka semakin tinggi minat beli ulang konsumen. Warung Kopi Klotok dalam mengemas indikator experiential marketing yang ditawarkan dalam hal ini 
Jurnal Manajemen Bisnis, Vol 10. No.1, Maret 2019, E-ISSN:2622-6308 P-ISSN:2086-8200

Website: http://journal.umy.ac.id/index.php/mb

DOI:10.18196/mb.10167

kesederhanaan dan suasana alami desa yang asri dengan kesesuaian dari yang diharapkan konsumen ketika mereka mengunjungi langsung ke lokasi, inilah faktor utama yang membuat konsumen tergerak untuk datang kembali dalam rangka melakukan beli ulang.

Nilai p-value pengaruh kepuasan konsumen terhadap minat beli ulang adalah 0,003 dengan $\mathrm{CR}$ bertanda positif sebesar 2,933. Oleh karena nilai $\mathrm{p}$ value yang diperoleh $<0,05$ dan C.R bertanda positif > 1,96, maka Ho ditolak dan disimpulkan bahwa kepuasan konsumen berpengaruh positif dan signifikan terhadap minat beli ulang. Semakin tinggi kepuasan konsumen maka semakin tinggi minat beli ulang konsumen. Sebagian dari konsumen Warung Kopi Klotok adalah wisatawan yang datang dari luar daerah, yang sedang berwisata di Yogyakarta, dan ingin menikmati sesuatu yang khas yang tidak mereka jumpai di daerahnya masing-masing, seperti sajian makanan dengan citarasa khas Yogyakarta dan suasana desa di kaki gunung yang asri alami, serta bangunan kuno dari warung ini yang mampu membawa nostalgia tersendiri bagi para pengunjung.

\section{Pengaruh Langsung dan Tidak Langsung}

Dalam penelitian ini, variabel kepuasan konsumen berperan sebagai variabel intervening yang memediasi pengaruh tidak langsung variabel experiential marketing terhadap minat beli ulang konsumen. Berikut ini adalah besar pengaruh langsung experiential marketing terhadap minat beli ulang dan besar pengaruh tidak langsung experiential marketing terhadap minat beli ulang dengan dimediasi oleh variabel kepuasan konsumen:

Tabel 5

Pengaruh Langsung dan Tidak Langsung

Standardized Direct Effects (Group number 1-Default model)

\begin{tabular}{lccc}
\hline & EM & KK & MBU \\
\hline KK & .914 & .000 & .000 \\
MBU & .347 & .534 & .000 \\
\hline
\end{tabular}

Standardized Indirect Effects (Group number 1-Default model)

\begin{tabular}{llll}
\hline & EM & KK & MBU \\
\hline KK & .000 & .000 & .000 \\
MBU & .488 & .000 & .000 \\
\hline
\end{tabular}

Sumber: Data diolah (2018)

Berdasarkan hasil analisis pada tabel di atas, dapat dilihat bahwa nilai pengaruh langsung variabel experiential marketing terhadap minat beli ulang adalah sebesar 0,347, sedangkan 
Jurnal Manajemen Bisnis, Vol 10. No.1, Maret 2019, E-ISSN:2622-6308 P-ISSN:2086-8200

Website: http://journal.umy.ac.id/index.php/mb

DOI:10.18196/mb.10167

nilai pengaruh tidak langsung variabel experiential marketing terhadap minat beli ulang adalah sebesar 0,488 . Oleh karena nilai pengaruh tidak langsung lebih besar dibandingkan nilai pengaruh langsung, maka dapat disimpulkan bahwa variabel kepuasan konsumen dapat memediasi pengaruh experiential marketing terhadap minat beli ulang dengan baik. Indikator experiential marketing yang ditawarkan oleh Warung Kopi Klotok, Kaliurang, Yogyakarta menimbulkan kepuasan konsumen merasa senang dengan apa yang semestinya ada dari sebuah warung kopi di desa yaitu suasana santai, nyaman, dan asri, serta makanan dan bangunan khas desa, yang kemudian berlanjut menjadi sebuah hal yang menarik minat mereka untuk melakukan beli ulang karena rindu akan suasana kesederhanaan yang alami.

\section{KESIMPULAN}

Berdasarkan hasil analisis data diperoleh kesimpulan sebagai berikut:

Dalam penelitian ini elemen experiential marketing yang paling dominan adalah relate pada indikator (dimana pelanggan ingin membagikan pengalaman kuliner di Warung Kopi Klotok kepada teman dan orang lain yang menyukai suasana desa yang alami), disusul kemudian oleh sense pada indikator (adanya ketertarikan pengunjung untuk menikmati suhu udara yang sejuk dan segar), act pada indikator (konsumen tertarik karena gaya yang berbeda dan unik), feel pada indikator (merasa nyaman menikmati lingkungan asri pedesaan), think pada indikator (keinginan untuk merasakan suasana khas desa). Dari indikator-indikator dominan terlihat bahwa konsumen memperoleh sebuah pengalaman menarik ketika berkunjung ke Warung Kopi Klotok, sehingga menimbulkan kepuasan konsumen dan memicu tindakan untuk melakukan beli ulang di masa mendatang.

Hipotesis 1 diterima yaitu experiential marketing berpengaruh positif dan signifikan terhadap kepuasan konsumen. Semakin tinggi experiential marketing maka semakin tinggi kepuasan konsumen. Hasil penelitian ini sejalan dengan hasil penelitian yang disusun oleh Kanoipate (2015), Tanzil dkk (2017), Oeyono \& Dharmayanti (2013), Tetanoe \& Dharmayanti (2014), Christian \& Dharmayanti (2013), Zena \& Hadisumarto (2012), Khasanah, Imroatul (2015), Razanah, Kumadji \& Kusumawati (2013), Yang (2009), Hyunjin (2003), Ozturk (2015), Lee et.al (2010), Ming (2010), yang menunjukkan bahwa experiential marketing berpengaruh positif signifikan terhadap kepuasan konsumen.

Hipotesis 2 diterima yaitu experiential marketing berpengaruh positif dan signifikan terhadap minat beli ulang. Semakin tinggi experiential marketing konsumen maka 
Jurnal Manajemen Bisnis, Vol 10. No.1, Maret 2019, E-ISSN:2622-6308 P-ISSN:2086-8200

Website: http://journal.umy.ac.id/index.php/mb

DOI:10.18196/mb.10167

semakin tinggi minat beli ulang konsumen. Hasil penelitian ini sejalan dengan hasil penelitian yang disusun oleh Setyono dkk (2017), Tetanoe \& Dharmayanti (2014), Yang (2009), Hyunjin (2003), Razi \& Lajevardi (2016), Lunette \& Andreani (2017) bahwa experiential marketing berpengaruh terhadap minat beli ulang.

Hipotesis 3 diterima yaitu kepuasan konsumen berpengaruh positif dan signifikan terhadap minat beli ulang. Semakin tinggi kepuasan konsumen maka semakin tinggi minat beli ulang konsumen. Hasil penelitian ini sejalan dengan hasil penelitian yang disusun oleh Sebopa (2016), Hyunjin (2013), Tetanoe \& Dharmayanti (2014), Yang (2009) yang menyimpulkan bahwa terdapat pengaruh positif dan signifikan variabel kepuasan pelanggan pada minat beli ulang.

Hipotesis 4 diterima yaitu kepuasan konsumen mampu memediasi pengaruh experiential marketing terhadap minat beli ulang dibuktikan dengan hasil uji nilai pengaruh tidak langsungnya lebih besar dibandingkan dengan nilai pengaruh langsung variabel experiential marketing terhadap minat beli ulang. Hasil penelitian ini sejalan dengan hasil penelitian yang disusun oleh Christian \& Dharmayanti (2013).

\section{KETERBATASAN PENELITIAN}

Keterbatasan dalam penelitian ini meliputi: (1) Penelitian ini hanya menggunakan satu variabel eksogen. (2) Penelitian terkait variabel experiential marketing terhadap kepuasan konsumen dan minat beli ulang dilakukan di objek Warung Kopi Klotok Kaliurang Yogyakarta. (3) Responden penelitian ini terbatas pada pengunjung yang sedang berada di lokasi penelitian pada saat penyebaran kuesioner yang diizinkan di luar hari libur (pada saat pendistribusian kuesioner mayoritas yang bersedia untuk mengisi kuesioner yang adalah pengunjung yang berpredikat sebagai mahasiswa). Jika pendistribusian kuesioner dilakukan di hari libur maka responden lebih variatif karena banyak pengunjung rumah makan ini yang berasal dari luar Yogyakarta.

\section{SARAN BAGI PENELITI SELANJUTNYA}

Saran bagi peneliti selanjutnya yaitu : (1) Sebaiknya untuk variabel eksogen mungkin bisa ditambahkan variabel lainnya yang relevan dengan topik penelitian seperti: variabel nilai pelanggan, word of mouth, kepercayaan, service quality, dan lain-lain. (2)Penelitian terkait variabel experiential marketing terhadap kepuasan konsumen dan minat beli ulang mungkin 
Jurnal Manajemen Bisnis, Vol 10. No.1, Maret 2019, E-ISSN:2622-6308 P-ISSN:2086-8200

Website: http://journal.umy.ac.id/index.php/mb

DOI:10.18196/mb.10167

perlu dicoba teliti di bisnis kuliner atau rumah makan yang lain, sehingga generalisasi hasil penelitian bisa lebih luas. (3) Sebaiknya menyasar responden dengan data responden yang lebih variatif lagi (pada hari libur banyak pengunjung dari luar daerah) untuk mendapatkan jawaban kuesioner yang lebih variatif juga.

\section{DAFTAR PUSTAKA}

Adam, M. (2015), Manajemen Pemasaran Jasa Teori dan Aplikasi, Cetakan Kesatu Maret 2015, Bandung: Penerbit Alfabeta.

Andreani, F. (2007), Experiential Marketing (Sebuah Pendekatan Pemasaran). Jurnal Manajemen Pemasaran, Vol. 2, No. 1. April 2007: (1-8).

Candra, H. (2008), Marketing Untuk Orang Awam, Jakarta: Maxikom.

Christian, A. \& Dharmayanti, Diah. (2013), Pengaruh Experiential Marketing Terhadap Customer Satisfaction dan Customer Loyalty The Light Cup di Surabaya Town Square, (Online), Jurnal Manajemen Pemasaran Petra Vol. 1, No. 2, (2013) 1-3, Universitas Kristen Petra Surabaya.

Dharmayanti, D. \& Lokito, S.A.. (2013), Analisis Pengaruh Experiential Marketing, Customer Satisfaction, Terhadap Customer Loyalty Comedy Kopi di Surabaya. (Online), Jurnal Strategi Pemasaran, Jurusan Manajemen Pemasaran, Universitas Kristen Petra Surabaya.

Ghozali, I. (2014), Model Persamaan Struktural Konsep dan Aplikasi dengan Program Amos 22.0 Update Bayesian SEM, Semarang: Badan Penerbit Universitas Diponegoro.

https://marketing.co.id/experiential-marketing- pekerjaan-schmitt-belum-selesai/ (Artikel Online), Majalah Marketing, Zoel. (28 Agustus 2012), Experiential Marketing: Pekerjaan Schmitt Belum Selesai. (Portal Lengkap Dunia Marketing). Marketing.co.id.

https://www.bi.go.id/id/publikasi/kajianekonomiregional/yogya/contents/KEKR\%20DIY\%20TRIWU LAN\%204\%202017.pdf (Februari 2018), (Artikel Online), Publikasi Laporan Perkembangan Perekonomian DIY Triwulan IV 2017 oleh Bank Indonesia DIY, Kajian Ekonomi dan Keuangan Regional Daerah Istimewa Yogyakarta 2017. BI.go.id.

https://www.republika.co.id/berita/nasional/daerah/17/07/28/otrzuz428-jumlah-usahamenengahkecil-sleman-tertinggi-di-yogya (Artikel Online), Suryana, Wahyu. (Juli 2017), Jumlah Usaha Menengah Kecil Sleman Tertinggi di Yogya, Republika.co.id.

Hyunjin, Jeon. July (2013), The Effect of Experiential Markerting on Customer Satisfaction and Revisit Intention of Beauty Salon Franchise Stores, (Online), Journal of Fashion Business Vol. 17. No. 3 pp. 109-121, Koreascience Reference Linking Platform of Korea S\&T Journals, The Korean Society of Fashion Business, Associate Professor, Dept. of Beauty Art. Honam University.

Kanoipate, V. (May 2015), The Impact of Experiential Marketing Use on Customer Perceived Value and Satisfaction in Lithuanian Restaurants, (Online), ISM University of Management and Economics.

Kartajaya, H. (2004), Marketing In Venus, Jakarta: PT. Gramedia.

Khasanah, I. (Juni 2015), Analisis Pengaruh Nilai Pelanggan, Experiential Marketing dan Rasa Kepercayaan Terhadap Kepuasan Pelanggan (Studi Kasus Hotel Pondok Tinggal Magelang) (Online), Jurnal Studi Manajemen Organisasi 12, 10-20. E-Journal Undip Universitas Diponegoro. 
Jurnal Manajemen Bisnis, Vol 10. No.1, Maret 2019, E-ISSN:2622-6308 P-ISSN:2086-8200

Website: http://journal.umy.ac.id/index.php/mb

DOI:10.18196/mb.10167

Kotler, P. and Keller, Kevin Lane. (2012), Marketing Management, 14 th Edition, ISBN:978-013-210292-6, Global Edition, England: Published by Pearson Education Limited. Publishing as Prentice Hall

Kusumawati, A. (2011), Analisis Pengaruh Experiential Marketing Terhadap Kepuasan dan Loyalitas Pelanggan: Kasus Hypermart Malang Town Square (Matos), (Online), Jurnal Manajemen Pemasaran Modern, Vol.3, Januari-Juni 2011. Universitas Brawijaya Malang.

Lee, Ming-Shing.; Hsiao, Huey-Der.; \& Yang, Ming-Feng. (2010), The Study of the Relationships Among Experiential Marketing, Service Quality, Customer Satisfaction and Customer Loyalty. (Online). International Journal of Organizational Innovation (Online); Hobe Sound Vol. 3, Iss. 2, Fall 2010, 352-378, Far East University, Taiwan.

Lokito, S.A. \& Dharmayanti, D. (2013), Analisis Pengaruh Experiential Marketing dan Customer Satisfaction Terhadap Customer Loyalty Comedy Kopi Surabaya, Jurnal Strategi Pemasaran Publication Petra.ac.id, Manajemen Pemasaran, Universitas Kristen Petra, Surabaya.

Lunnette, C., Andreani, F. (2017), Kepuasan Experiential Marketing Terhadap Minat Beli Ulang di Gyu Kaku Galaxy Mall, (Online), Jurnal Hospitality dan Manajemen Jasa Vol. 5, No. 2, Manajemen Perhotelan, Universitas Kristen Petra, Surabaya.

Ming, Chou You. (2010), Study on the Impact of Experiential Marketing and Customers' Satisfaction Based on Relationship Quality, (Online), Department of Travel Management Hsing $\mathrm{Wu}$ College, Taiwan, R.O.C, The International Journal of Organizational Innovation Vol 3 Num 1 Summer.

Oeyono, J. T., \& Dharmayanti, Diah. (2013), Analisa Pengaruh Experiential Marketing Terhadap Loyalitas Konsumen Melalui Kepuasan Sebagai Intervening Variabel di Tator Cafe Surabaya Town Square, (Online), Jurnal Manajemen Pemasaran Vol. 1. No. 2, 1-9, Universitas Kristen Petra, Surabaya.

Ozturk, R. (2015), Exploring the Relationships between Experiential Marketing, Customer Satisfaction and Customer Loyalty: An Empirical Examination in Konya, (Online), World Academy of Science, Engineering and Technology International, Journal of Economics and Management Engineering, Vol. 9, No. 8, Digital Open Science Index, Economics and Management Engineering, International Scholarly and Scientific Research $\mathcal{E}$ Innovation.

Pine, Joseph II, and Gilmore, James H. From the (July-August 1998), Welcome to the Experience Economy. Harvard Business Review.

Razanah, Z.; Kumadji, S.; \& Kusumawati, A. (Januari-Juni 2011), Penerapan Experiential Marketing Strategi dan Pengaruhnya Terhadap Kepuasan dan Loyalitas (Studi pada pelanggan bakso Cak Kar Singosari-Malang, (Online), Jurnal Manajemen Pemasaran Modern Vol.3, No. 1, ISSN 2085-0972, Universitas Brawijaya Malang.

Razi, Farshad Faezy.; and Lajevardi, Masoud. (2016), Sense Marketing, Experiential Marketing, Customer Satisfaction, and Repurchase Intention, (Online). ISSN 2422-8451 An International Peer-reviewed Journal. Vol.21, 67.

Schmitt, B. H. (1999), Experiential Marketing: How To Get Customers To Sense, Feel, Think, Act, and Relate to Your Company and Brands, The Free Press, New York.

Schmitt, B.H. (1999), Marketing: A New Framework for Design and Communications, http://id.booksc.org/book/18488378/9b839f (Online E-Book), Design Management Experiential Journal , Vol.10, No.2, Spring 1999. 
Jurnal Manajemen Bisnis, Vol 10. No.1, Maret 2019, E-ISSN:2622-6308 P-ISSN:2086-8200

Website: http://journal.umy.ac.id/index.php/mb

DOI:10.18196/mb.10167

Sebopa, B.C. (2016), Experiential marketing as a predictor of repurchase intentions of Smartphones amongst youth in South Africa. (Online), University of the Witwatersrand Johannesburg.

Setyono, D.; Widyanata, Ong Yinyin.; Siaputra, Hanjaya.; \& Jokom, Regina. (2017), Analisa Pengaruh Experiential Marketing terhadap Minat Beli Ulang Konsumen Konig Coffee \& Bar, (Online), Jurnal Hospitality dan Manajemen Jasa, Vol. 5, No. 1, Manajemen Perhotelan, Universitas Petra Surabaya.

Smilansky, S. (2009), Experiential Marketing: A Practical Guide to Interactive Brand Experiences, London and Philadelphia: Kogan Page.

Solomon, M. R. (2004), Consumer Behavior Buying, Having, and Being, International Edition, Sixth Edition, ISBN 0-13-123011-5, Pearson Education International, Saddle River, New Jersey, Pearson Prentice Hall.

Suryadana, M. Liga \& Octavia, Vanny. (2015), Pengantar Pemasaran Wisata, (Visit Indonesia Every Time Remembered with Beauty), Cetakan Kesatu Mei 2015, Bandung: Penerbit Alfabeta.

Tanzil, G. Irawan, I.; \& Aprilia, A. (2017), Analisa Konsep Sizzling Steak Yang Merupakan Experiential Marketing Terhadap Minat Pembelian Ulang Konsumen Di Restoran Pepper Lunch Tunjungan Plaza Surabaya, (Online), Jurnal Hospitality dan Manajemen Jasa Vol.5 No. 1. 2017, Manajemen Perhotelan, Universitas Petra Surabaya.

Tetanoe, Vinsensius Ronald \& Dharmayanti, Diah. (2014), Pengaruh Experiential Marketing Terhadap Pembelian Ulang Dengan Kepuasan Pelanggan Sebagai Variable Intervening di Breadtalk Surabaya Town Square, (Online), Jurnal Strategi Pemasaran Petra Vol. 2, No. 1, (2014) 1-12, Universitas Kristen Petra Surabaya.

Tjiptono, F. (2014), Pemasaran Jasa, Yogyakarta: CV. Andi Offset.

Unjaya, Go Darmadi, \& Santoso, L. (2015), Analisis Pengaruh Satisfaction, Trust, Commitment Terhadap Repurchase Intention Pelanggan Tetap Hotel Raden Wijaya Mojokerto, (Online), Jurnal Hospitality dan Manajemen Perhotelan, Manajemen Perhotelan, Universitas Kristen Petra Surabaya, Indonesia.

Yang, Chih-Yun. (2009), The Study of Repurchase Intention in Experiential Marketing an Empirical Study of the Franchise Restaurant, (Online). International Journal of Organizational Innovation, Vol 2, Num 2, Fall 2009, Department of Hospitality Marketing Management National Kaohsiung Hospitality College, Taiwan.

Zena, P.A. \& Hadisumarto, A.D. (2012), The Study of Relationship Among Experiential Marketing, Service Quality, Customer Satisfaction and Customer Loyalty, Asean Marketing Journal Vol. IV, No. 1, June 2012. 